\title{
Technology Upgrading, Learning, and Exports among Manufacturing Firms in a Liberalizing Environment
}

\author{
Wise Mainga, \\ Tri D. Lam, \\ University of the Bahamas, Bahamas
}

URL:http://dx.doi.org/10.19044/esj.2020.v16n25p30

\begin{abstract}
This paper focuses on examining the empirical relationship between technology upgrading, disaggregated skills upgrading variables, and exports among manufacturing firms in the Greater Johannesburg Metropolitan Council (GJMC). The importance of skill development as a determinant of value-added in export basket, and the latter's subsequent impact on economic development, is widely acknowledged. The analysis of the relationship between disaggregated training variables and exports are rare. The data used in this study comes from the joint World Bank/Greater Johannesburg Metropolitan Council co-ordinated survey of large manufacturing firms, within the Greater Johannesburg Metropolitan Council (GJMC) area. Some of the key findings of the paper are as follows. First, the data analysis supports the perspective that different knowledge accumulation channels (or learning mechanisms) may have differential impact on exports; Imports and exports tend to be complementary, thereby re-enforcing firm-level learning and capability building. Dynamic capability building can take place if exporting activities drives the importation of capital goods. Second, recently introduced product lines had a positive impact on exports, suggesting the importance of frequent product upgrading/product innovations in exploiting competitive and demanding export markets. Third, a lot of training offered to different occupational groups did not seem to have any significant impact on exports. The results raise questions about the quality, content, and focus of employment-based training programs. One major implication of the study findings is that skill upgrading of 'unskilled production workers' through inhouse firm-based training is key to ensuring production of quality 'exportgrade' output. The importance of frequent product upgrading when targeting demanding export markets suggests the need to have policy objectives that strengthen the National Innovation System.
\end{abstract}


Keywords: Exports, Technological capabilities, Technological upgrading, Training, Manufacturing firms

\section{Introduction}

Relatively little review has been done on the impact of disaggregated technological learning variables on the performance of the manufacturing sector in South Africa. Where technological learning and capacity issues are tackled, they are often taken as aggregates. In most studies in South Africa and elsewhere, technological capacity is often seen as an all-encompassing unexplained residual representing 'technological change' in growth accounting econometric analyses (Felipe \& McCombie, 2003; Tam \& Gereffi, 1999). Macroeconomic models of economic growth often take technological progress/development in very highly abstract terms, which often makes very little sense to business leaders or policy makers (Tam \& Gereffi, 1999; Bhavani, 2002). The role of "internal effort" of firms in building technological competencies needed to produce products whose quality and price can compete in very demanding international markets has often (until relatively recently) received secondary attention (Wignaraja, 2007; Lall, 1992,1996; Lauridsen, 2002; Perez-Aleman, 2000). As a result, enterprise-level technological development and adjustment is often seen as a process that can be implemented relatively easily and within a shorter period (Lall \& Latsch, 1998). Despite patchy coverage in the context of developing countries, building of technological capabilities and continuous technological upgrading underpins dynamic comparative advantage needed to acquire, maintain, and expand competitive positions in international markets (Perez-Aleman, 2000; Galhardi, 1999; Ernst et al., 1998; Mainga, 2001; Bhavani, 2002). It is also such capabilities that enable firms, sectors, and nations to eventually move incrementally into higher productive, higher value-added industries (Diao et al., 2006; Gries, 2002; Karaoz \& Albeni, 2004; Perez-Aleman, 2000). Differences in efficiency with which firm-level capabilities are built-up vis-àvis competitors can, in itself, constitute a competitive advantage for domestic firms in both domestic and international markets (Wignaraja, 2001; 2007; Narayanan, 1998; Figueiredo, 2002).

International competitiveness is increasingly being driven by greater knowledge intensity of production (Canuto et al., 2010; Narayanan, 1998; Okada, 2004). The increase in knowledge intensity of production is perverse in many sectors (Mital et al., 1999; Mytelka \& Tesfachew, 1998; Berman et al., 1998; Machin \& Van Reenen, 1998). This has, in turn, increased the importance of workers' skills and technical competence. Skilled workers are more adept to change and at learning or assimilating new knowledge required for continual adjustments to changing operating conditions (ILO, 2011; 
Okada, 2004; Basant \& Chandra, 2002; Solleiro \& Castanon, 2004). The aggregate level of skills - both at the firm-level and national-level - determines the possibility of accelerating technological growth, and is a critical factor in meeting the 'switching condition' from stagnation/slow growth to dynamic take-off (Gries, 2002; Bond et al., 2005; Keller, 1996). In fact, most endogenous theorists, evolutionary economists, and management literature on 'capability-building' emphasise the importance of increased international flow of knowledge across firms and countries as a critical determinant of the rate of economic growth (Dahlman, 2007; Rivera-Batiz \& Romer, 1991; Young, 1991).

It is with such a view in mind that this paper focuses on the relationship between intra-firm knowledge accumulation/skill development, technology, and exports of South African manufacturing sector in the reform period. One benefit of a more open trade regime is the perceived growth benefits of expanded exports, which is made possible by enhanced imperatives to undertake technological-upgrading that underpin firm-level restructuring in such economies (Madanmohan et al., 2004; Okada, 2004; Perez-Aleman, 2000; Jonker et al., 2006).

This study focuses on the South African manufacturing sector and manufactured exports, in particular, for a number of reasons. Firstly, the importance of the manufacturing sector in any developing economy to act as a catalyst for the development of other sectors through its multiplier effects and value chain linkages is well acknowledged and supported in the literature (Pan-African Investment \& Research services, 2011; Deloitte, 2013). Secondly, the sector - especially manufacturing exports - is seen as vital in inducing economic growth through access to larger global markets, increased job creation, enhanced income for companies and employees working for exporting firms, technological upgrading, positive knowledge spillovers, productivity improvement, and competitiveness throughout the economy (Matthee et al., 2016; Diao et al., 2006). Thirdly, the performance of the manufacturing sector in a middle income country like South Africa, with some degree of manufacturing sophistication, can provide useful policy lessons and dilemmas for other developing countries that are trying to integrate with the global economy through trade liberalization (Edwards \& Alves, 2005). Fourthly, despite the potential exporting presents as an engine of economic growth, the growth of South African manufactured exports in overseas markets - in terms of volumes and global market share - have been lustre at best (Rodrik, 2008). South African manufacturers seem to have lost both domestic and global market shares of manufactured goods to Asian competitors like India and China (Edwards \& Jenkins, 2013). For example, China's manufactured exports to the South African domestic market have steadily increased their market share from $0.5 \%$ in 1995 to $6 \%$ by 2010 
(Edwards \& Jenkins, 2013). Most of this Chinese import penetration of the South Africa domestic market has been at the expense of local manufacturers. This downward trend was further exacerbated by the 2008 global economic crisis, exposing binding structural constraints facing the sector that included shortage of critical skills, infrastructural bottlenecks, rising input costs, energy shortages, limited product market competition, and unfavourable macroeconomic policies (Faulkner et al., 2013; Anand et al., 2016). By 2010, manufacturing output as a percentage of GDP had dropped to only $17 \%$, with its growth rate hovering around 5\% (Pan-African Investment \& Research services, 2011). This was way below the performance of peer countries like Thailand, Turkey, Argentina, and Brazil (Pan-African Investment \& Research services, 2011). In fact, the sluggish rebound of the economy from the effects of the 2008 global economic crises - relative to peer countries - is partly pinned down to the loss of competitiveness of the manufacturing sector over time (Rodrik, 2008; Anand et al., 2016). This is exemplified by the pattern of evolution that has taken place within the export basket. Kaplan (2014) compares South Africa among an association of five major emerging national economies, in relation to technology intensive manufacturing and exports. The association comprises of Brazil, Russia, India, China, and South Africa (BRICS). Of the five BRICS countries, South Africa had the smallest share of high technology exports of total manufactured exports, and that share had been declining over time. By 2010, that share stood at $4.28 \%$. This was in contrast to Brazil's 11.4\%, Russia's 8.85\%, and India's 7.2\% (Kaplan, 2014). One of the study on 'Global Manufacturing Competitiveness Index' showed South African manufacturing dropping two places in 2012 (Deloitte, 2013). Moreover, the same research projected that South Africa would continue to drop in its ranking for the next five years. The relative decline in growth rate in manufacturing competitiveness, especially with regard to dynamic and high technology products, has in turn deprived South Africa of some growth opportunities (Rodrik, 2008; Edwards \& Alves, 2005). In this paper, we focus mainly on the relationship between technology, skills and manufactured exports. The main contribution of the paper is to add empirical evidence to a growing number of studies that directly link technological capabilities (and/or technological learning) to some indicators of firm performance during the period after the introduction of economic structural reforms (Wignaraja, 2007).

The rest of the paper is organised as follows. In Section 2, we present a review of the literature underpinning Firm-level learning, Technological upgrading, and Exports - especially in the era of increased globalization. Section 3 briefly outlines the methodology, before reporting on the data analysis undertaken. To economise on space, most of the descriptive analysis that had accompanied the statistical analysis presented in this paper have been 
left out. Section 4 outlines some conclusions and possible lessons for other resource-based economies which are contemplating their own integration into the global economy. The section ends by acknowledging some of the limitations of the study and suggesting possible directions for future research.

\section{Literature Review \\ Firm-Level learning}

The analytical framework is based on conceptual perspectives used by several researchers (Aw et al., 2007; Caniels \& Romijn, 2003; UNIDO, 2003; Jonker et al, 2006). In an increasingly integrated world economy, knowledge possessed by domestic firms has become a critical strategic resource which is crucial to achieving and sustaining international competitiveness (Bastos et al., 2016; Navaretti et al., 2004; Okada, 2004). This is accurate when operating in today's global markets, characterised by rapid technological change, frequent innovations, increased uncertainty, shortened product life-cycles, rapid shifts in product markets, and heightened international competition (Dahlman, 2007; Madanmohan et al., 2004). Different types of 'knowledge' underpin the complex bundles of capabilities a firm needs to possess to survive in the era of globalization (Hudson, 1999). The knowledge-based view places the firm as the central actor in the process of building technological capabilities needed for export-oriented development (Ernst et al., 1998). Accumulation of technological capabilities requires a purposeful investment in the acquisition of competitive skills, knowledge, and experience which is needed to efficiently acquire, operate, and continuously improve imported productive technology (Wignaraja, 2007; Bell \& Pavitt, 1993). Such accumulation efforts are driven by various learning processes undertaken as a result of interactions inside firms, between firms, between firms and institutions, and between firms and the State (Faulkner et al., 2013; PerezAleman, 2000; Lauridsen, 2002; Uchida \& Cook, 2005).

Learning is seen as a complex process of creating or acquiring new knowledge, and/or upgrading existing knowledge-base (Hudson, 1999; Jonker et al., 2006). Effective learning requires more than exposure to new knowledge or information. Learning requires explicit 'technological effort', and an explicit firm-level strategy in developing and upgrading the knowledge-base. Moreover, a firm's ability to assimilate 'new' knowledge is a function of its current 'knowledge-base' or 'absorptive capacity' (Wignaraja, 2007; Keller, 1996). Therefore, it is necessary that the "appropriate contextual knowledge necessary to make the "new' knowledge fully intelligible" pre-exist (Cohen \& Levithal, 1990). Continuous acquisition of new knowledge, skills, and competencies underpin the (dynamic) adaptive abilities required to continuously absorb and implement new technologies, improve the performance of production processes and products (i.e., in terms of efficiency, 
quality, features, cost, etc.), and institute the necessary re-organisation of production (Iyigun \& Owen, 2005). The learning and capability-building process is seen to be incremental and cumulative, path-dependent, unpredictable, involves various interactions with other (national \& international) economic agents, and it is impacted by national policy and complementary institutional factors (Brambilla et al., 2015; Aw \& Batra, 1998; Bell \& Pavitt, 1993).

\section{Technological Upgrading and Exports}

A firm's technological effort is partly a function of various internal and external stimuli emanating from its operating environment. Internal stimuli might be, for example, due to frequent machine breakdowns, growing quality problems, or declining sales. External stimuli might be, for example, demand changes as conveyed by international buyers, upgrading strategies of Transnational Corporations (TNCs) that may dictate adjustment of local suppliers, change in trade policy orientation, and increased competitive pressures (Caniels \& Romijn, 2003; UNIDO, 2003). The last type of external stimuli is especially important. Greater openness to international trade induces competitive or imperative pressure/incentive for frequent upgrading of productive technologies. This precipitates the need for continuous upgrading of workers' skills, who have to efficiently use such up-to-date technologies (Beerepoot, 2004). It is the complementarities between upgrading of physical capital (technological upgrading/capital deepening) with the upgrading of labour skills that underpinned the rapid export growth witnessed in successful East Asian economies (Aw et al., 2007; Diao et al., 2006; Ernst et al., 1998; Uchida \& Cook, 2005). Consistent and continuous upgrading of such capabilities facilitated the production of quality 'export-grade' output that can compete in very demanding international markets (Mital et al., 1999; Brambilla et al., 2015).

The ability of a firm to be competitive in today's globalized world partly lies in being able to access complementary assets and knowledge located in other firms in the value chain (i.e., suppliers, international buyers, strategic partners, competitors, TNCs, etc.) and in external institutions (i.e., factor markets, technological infrastructure, universities, political and legal framework, trade associations, etc.) (Okada, 2004; Uchida \& Cook, 2005; Yun, 2003). It is, therefore, important for firms to have strong interactive linkages to various external sources of knowledge and capabilities. In particular, proactive linkages with global TNCs have been found to be especially critical in facilitating technological upgrading of local firms in developing countries (Yunus et al., 2015; Wignaraja, 2007; Hobday, 1995; Gereffi, 1999; Tam \& Gereffi, 1999). 
While the above analytical framework is helpful in explaining the relationship between learning and technological upgrading, there are still gaps in past empirical work. For example, the above literature review seems to imply that knowledge is a homogenous factor. However, knowledge exists in various forms and/or types (Beerepoot, 2004; Hudson, 1999). Consequently, accumulation of different 'skill-mixes' can lead to inter-firm differences in economic performance (Figueiredo, 2002).

Moreover, there are different types of learning processes involved: learning-by-doing, learning-by-using, learning-by-interacting, learning-bysearching, learning-by changing/experimentation, learning-by-hiring, learning-by-exporting, learning-by-imitation/reverse engineering, and learning-by-adaptive/generative R\&D (Aw, 2007; Bell, 1984; Nelson, 1981). Different types of learning processes and their combinations might be critical determinant in building different types of capabilities. "Competitiveness and economic success is thus seen to be grounded in a variety of types of knowledge and knowing" (Hudson, 1999). Consequently, different portfolios of learning processes might lead to different capabilities (both in terms of quality \& level).

It is this heterogeneity in accumulation of knowledge, in the type of knowledge accumulated (i.e., know-how, know-what, know-who), in the speed with which it is accumulated and in the way in which it is combined, that determine the sustained competitiveness of a firm vis-à-vis its competitors. One of the shortcomings of (mostly qualitatively-based) literature on technological capabilities has been the lack of discrimination on the unique characteristics of each learning process (or knowledge accumulation mechanism), and how such unique characteristics can be shown statistically to have a differential impact on building different capabilities (Rankin, 2013; Aw et al., 2007).

Realising such deficiencies in past research, this study deliberately focuses on disaggregated learning variables - acknowledging that different knowledge-types are accumulated through different 'knowledgeaccumulating channels' used by firms. The empirical section attempts to answer a few broad questions;

i. Which disaggregated learning or knowledge accumulation mechanisms were associated with Exports in South African manufacturing firms?

ii. What other factors were found to have an impact on Exports?

iii. Which training programs offered to different occupational groups was associated with export capabilities of manufacturing firms? 


\section{Methodology and Survey Data Analysis}

Matthee et al. (2016) and Rankin (2013) have alluded to the problem of lack of comprehensive firm-level datasets in South Africa that are comparatively readily available in other countries. Kleynhans and Labuschagne (2012) made a compelling case of the non-existence of reliable data on human capital development in South Africa. The data used in this study comes from the joint World Bank/Greater Johannesburg Metropolitan Council co-ordinated survey of large manufacturing firms, within the Greater Johannesburg Metropolitan Council (GJMC) area. A large firm was defined as one with 50 or more full-time employees. The organization contracted to manage the survey was the Bureau for Market Research (BMR). The survey was done in 1999. The sampling started with the national census of 6174 manufacturing firms. Working from this census, a (regional) sampling frame of 2346 firms within the Greater Johannesburg area was created. In getting the final sample, firms were stratified into eight manufacturing subsectors (Table 1) and three full employment class sizes (Table 2). The three full employment class sizes were: small (50-99 employees), medium (100-199 employees), and large (200-10000 employees). Random sampling was applied to the multistage strata. 369 firms were surveyed. Out of these firms, only 325 firms were able to provide full responses. A more detailed analysis of sampling and weighting procedures is given in Chandra et al. (2001). At the time of this study, the GJMC manufacturing firms' survey was the only firm-level dataset easily accessible in South Africa that had disaggregated training variables according to different occupational groups. The GJMC area within which the survey was conducted accounts for $40 \%$ of South Africa's large manufacturing firms, and about $42 \%$ of the country's formal manufacturing employment (Chandra et al., 2001). While the survey is not national in nature, the area covered by the survey is seen to represent a large segment of the manufacturing sector to significantly inform public policy and other stakeholders (Edwards, 2002). By using firm-level survey data, the impact of firm heterogeneity can be picked up more easily, in a way that sectoral, national, and/or regional surveys would not (Edwards, 2002). The focus of the paper is on the first decade of economic reform period, when the South African government undertook decisive and comprehensive structural reforms.

Table 1 covers the eight subsectors represented in the survey: Food \& Beverages, Textiles, Metal products, Iron \& Steel, Electrical/electronic machinery, Paper \& furniture, Vehicles \& automotive components, and Chemicals. The largest number of firms were drawn from three subsectors: Metal products, Electronics \& electrical machinery, and Iron \& steel. Fewer firms were drawn from the Textile subsector. Only $4 \%$ were from this subsector. Most textile firms in the country are located outside the Greater Johannesburg Metropolitan area. Subsectors with the largest share exported 
are: vehicles \& auto parts, Iron \& steels, and Electronics \& electrical machinery. At the time of the survey, Textiles and Furniture \& paper subsectors exported the least of their respective output. Table 2 gives the size distribution of firms that were surveyed. A larger number of firms fell in the 'small firm' category (50-99 employees), with the other two class sizes almost balanced out.

Table 1. Number of firms by manufacturing subsector, export share

\begin{tabular}{|l|c|c|c|}
\hline Subsector & No. of firms & $\begin{array}{c}\text { Share by } \\
\text { subsectors } \\
(\mathbf{\%})\end{array}$ & $\begin{array}{c}\text { Average share of } \\
\text { output exported } \\
(\mathbf{\%}) *\end{array}$ \\
\hline Metal products & 57 & 17.54 & 18.3 \\
\hline Furniture \& paper & 34 & 10.46 & 8.0 \\
\hline Electronics \& electrical machinery & 56 & 17.23 & 19.4 \\
\hline Iron \& steel & 56 & 17.23 & 22.6 \\
\hline Food \& beverages & 26 & 8.00 & 14.3 \\
\hline Chemicals & 48 & 14.77 & 12.0 \\
\hline Vehicles \& auto parts & 34 & 10.46 & 27.3 \\
\hline Textiles & 14 & 4.31 & 9.1 \\
\hline Total & $\mathbf{3 2 5}$ & $\mathbf{1 0 0}$ & $\mathbf{1 6 . 4}$ \\
\hline \multicolumn{4}{|l|}{ Only exporters were included in export values (1998) } \\
\hline
\end{tabular}

Table 2. Size distribution of surveyed firms

\begin{tabular}{|l|c|c|}
\hline Firm size & Number of firms & \% share \\
\hline 50-99 employees & 145 & 45 \\
\hline 100-199 employees & 88 & 27 \\
\hline 200+ employees & 92 & 28 \\
\hline Total & $\mathbf{3 2 5}$ & $\mathbf{1 0 0}$ \\
\hline \multicolumn{2}{|c|}{ Source: Computed from World Bank/GJMC Survey dataset } \\
\hline
\end{tabular}

The statistical analysis presented below focuses on one market-related performance capability - exports. The statistical analysis was obtained from the methodologies used in Pavcnik (2003), Kokko et al. (1996), and Soderbom and Teal (2000). We used two versions of the 'Dependent variable': (i) amount of exports normalised by productive physical capital, and (ii) percentage of total output that is exported. Ordinary Least Square (OLS) multiple regressions are used in the analysis of survey data. OLS multiple regressions are often used not just for their relative simplicity, but also because they provide the 'best fit' for a specific dataset and the minimal residue value (Kleynhans \& Labuschagne, 2012). One of the advantages of using multiple regression equations is the possibility of capturing the nature of the relationship between the Dependent and Independent variables in the presence of other variables. The OLS regressions used took the following format; 
$\mathrm{CP}_{\mathrm{i}}=\mathrm{a}+\mathrm{b}_{\mathrm{i}} \mathrm{X}_{\mathrm{i}}+\mathrm{b}_{\mathrm{j}} \mathrm{CV}_{\mathrm{j}}+\mathrm{e}$

Where;

$\mathrm{CP}_{\mathrm{i}}=$ Firm-level market capability (amount exported $/ \mathrm{K}, \%$ of output exported)

$\mathrm{a}=$ a regression constant

$\mathrm{b}_{\mathrm{i}}, \mathrm{b}_{\mathrm{j}}=$ regression coefficients

$\mathrm{X}_{\mathrm{i}}=$ vector of firm-level knowledge accumulation mechanisms (i.e., on-the-job

training, off-the-job training, other learning mechanisms, etc.)

$\mathrm{CV}_{\mathrm{j}}=$ vector of various control variables (i.e., capital-intensity, subsector dummy, firm-size, Trade Association membership, ownership type, etc.)

$\mathrm{e}=$ error term

A more detailed description of individual variables is shown in Table 3 where regression equations are recorded. Different specifications of regression equations were run to test the association of different variables on the dependent variable. Only final regressions results are shown. Two diagnostic tests were performed. Amongst all the regressions included in this paper, only those that passed the heteroskedasticity test (Cook-Weisberg test) are shown. In some regressions, the specification test (Ramsey RESET test) did reject the respective null hypothesis, suggesting some missing variables. This is partly due to the fact that the survey dataset we are using was not tailored specifically to answering some of the research questions we are addressing in this paper. As such, not all variables impacting on respective dependant variable were collected (i.e., for example, initial productivity levels, international linkage intensity, single product vs multi-products export status, etc.). It must be borne in mind that most of the findings discussed in this paper explain outcomes during the first decade of the reform period after the introduction of a liberalised environment. To be more specific, data was collected from 1998. We, however, also capture findings from other studies that used different datasets which support our findings.

\section{Export Competitiveness versus Knowledge Accumulation}

The regressions analysed are shown in Table 3. For the first three regressions, the dependent variable is the total amount exported, normalised by the 'replacement value' of all machinery and equipment owned by each firm. Amount of output exported is one of the important indicators of international competitiveness of local firms and industries in global markets (Ernst et al., 1998; Bastos \& Silva, 2010). An inter-industry study on Chinese 
industries found that more exported-oriented industries were technically more efficient than those industries whose products were oriented more towards the domestic market (Sun et al., 1999). A firm-level analysis of panel data from four African countries (Cameroon, Ghana, Kenya and Zimbabwe) also found that exporting firms were more efficient than non-exporting firms (Bigsten $e t$ al., 2000). The amount of output exported is, therefore, a good indicator of the competitive capability of local firms or industries in turbulent and more demanding international markets (Solleiro \& Castanon, 2004).

We began our analysis with Regression $1(\operatorname{Reg} 1)$ in Table 3.152 firms had data across all the regression variables. Capital-intensity is negatively related to the proportion of total output exported by firms. One of the possible explanations of the negative association is in line with much of the literature on the complementary relationship between technology upgrading/capital deepening and export-quality upgrading (Diao et al., 2006; Galhardi, 1999; Brambilla et al., 2015). Using this line of thought, firms facing declining exports sought to stem the negative impact on overseas sales by investing in new technology to raise their productivity, quality, and enhance their international competitiveness. Capital deepening among both exporters and none-exporters has been observed more generally in South African manufacturing sector (Rodrik, 2008; Edwards \& Lawrence, 2006). This, in turn, necessitated skill-upgrading, especially among unskilled production workers who survived initial retrenchments. An alternative explanation of the result shown in Table 3 is not entirely unique. Similar result has been found elsewhere, using different datasets. By analysing patterns of growth of manufactured exports using data from Department of Trade and Industry (DTI), Pretorius (2002) found that exports had increased after 1994 with the export basket changing in favour of labour-intensive exports. Examining firms along the 'technology dimension', Nordas (1996) found that South African manufacturing firms' competitiveness lay largely in low-technology industries. It must be acknowledged that some studies on South Africa's (aggregate) export structure tend to originate from more capital-intensive and/or resource-intensive sectors, which tend to re-enforce the country's natural comparative advantage in minerals and other resources (Tsikata, 1999; Edwards, 2001b; Bhorat, 2000). However, some of these studies may be based on national survey data. Examining each of South Africa's nine provinces, Suleman and Naude (2003) found that each province had different combinations of subsectors in which its competitiveness and comparative advantages resided. Given the characteristics of our sample, we must therefore be cautious when drawing wider conclusions about all firms across the whole country. There is increasing realization in recent literature of heterogeneity across firms, including differences in characteristics among exporters (Matthee et al., 2016; Rankin, 2013). A study by Naude (2006) found that 
export orientation was the greatest in Gauteng and KwaZulu-Natal provinces, when compared to firms in other provinces.

Initial growth in exports seemed to have been confined largely to certain sectors (\& probably most likely to certain firms within specific sectors). Relative to the Textile sector (Sectdum7), exports were significantly higher in Food processing \& beverages (Sectdum3), Iron \& Steel (Sectdum4), and Metal products (Sectdum5) subsectors. A sizeable number of firms located within the GJMC area were a product of past policies that aimed at extracting mineral 'rents' from natural/mineral resources that were located within and outside Gauteng. The relative higher exports of the 'Iron \& Steel' and 'Metal products' subsectors may, therefore, be linked to 'beneficiation' policies of past Apartheid governments (Tsikata, 1999; Alleyne \& Subramanian, 2001; Altman, 2001).

A cumulative effect of (past) cheap government finance availed to beneficiation projects, technological/production competencies that subsequently developed within policy-targeted 'input-supplying' sectors, past access to relatively cheaper raw materials and energy, and demand from government generated opportunities such as infrastructure building, interactively enhanced the relative competitiveness of the two sub-sectors after 1994 (Nordas, 1996; Fine \& Rustomjee, 1996; Roberts, 2000). For example, between 1993-1997, the bulk of IDC's industrial development funds went to large-scale and capital-intensive projects in the basic metals subsector, the likes of which were the Alusaf expansion, Columbus Stainless Steel, and Saldanha Steel (Edwards, 2001b). Another example is the inputsupplying 'Iron \& Steel' subsector, which developed pockets of 'state of the art' technology at the lower tail of the industry's product range (Nordas, 1996). The two subsectors represent a good example of cumulative, path-dependent technological development, where operating competence accumulated during the period of import substitution helped to kick-start exports during the economic reform period. In addition, growth of exports in the two subsectors was partly helped by the devaluation of the local currency (Rand) implemented in the immediate period after the introduction of structural reforms, and subsequent intra-industry specialisation that took place to achieve economies of scale and/or scope (Petersson, 2002). Intra-industry specialisation reduced production costs of domestic output by limiting the varieties of product lines produced, while product differentiation enabled the meeting of 'demand for variety' through imports (Petersson, 2002). The regression results partly supports research that have found an increased dependence on resource-based or commodity-intensity exports, as South Africa integrated further into the global economy (Anand et al., 2016; Altman, 2001). 
Table 3. Exports as Dependent Variable

\begin{tabular}{|c|c|c|c|c|}
\hline & \multicolumn{4}{|c|}{ Dependent Variable } \\
\hline & $(\operatorname{Reg} 1)$ & $(\operatorname{Reg} 2)$ & $(\operatorname{Reg} 3)$ & $(\operatorname{Reg} 4)$ \\
\hline & LExport/K & LExport/K & LExport/K & LExportPge \\
\hline Constant & 0.369 & 6.4770 & 3.3278 & 2.5282 \\
\hline LNewInvest & -0.2162 & -0.2120 & -0.2270 & -0.3181 \\
\hline LCapital/Employee & $-1.4540 * * *$ & $-1.6191 * * *$ & $-1.4539 * * *$ & $-1.3071 * * *$ \\
\hline ForgnOwnShp & -0.2190 & 0.1434 & -0.0942 & -0.4099 \\
\hline Sectdum1 (Chemical Products) & 1.4627 & 0.3516 & 1.2578 & 1.8000 \\
\hline Sectdum2 (Electrical Machinery) & 1.6229 & 0.2448 & 1.4309 & 0.1192 \\
\hline Sectdum3 (Food Processing) & $2.5309^{*}$ & 2.4141 & $2.5557^{*}$ & 2.4831 \\
\hline Sectdum4 (Iron \& Steel) & $2.5433^{*}$ & 0.9677 & $2.2969^{+}$ & 1.0319 \\
\hline Sectdum5 (Metal Products) & $1.8996^{+}$ & 0.5617 & 1.7090 & 1.2826 \\
\hline Sectdum6 (Paper \& Furniture) & 0.3089 & -1.0743 & 0.0839 & 0.1157 \\
\hline Sectdum8 (Vehicle \& automotive) & 1.7421 & 0.7430 & 1.5895 & 0.8326 \\
\hline LInhseSpTrng & 0.0487 & 0.1947 & 0.0409 & -0.1367 \\
\hline LOstSpTrng & 0.0881 & 0.1573 & 0.1233 & $0.5174^{*}$ \\
\hline TrainMgtPgeI & -5.0743 & -4.2129 & -3.7761 & -2.4447 \\
\hline TrainPflPgeI & 1.7362 & $3.5670^{+}$ & 1.5213 & 0.1202 \\
\hline TrainClcPgeI & -0.8389 & -1.0690 & -1.0525 & -3.2033 \\
\hline TrainCrftPgeI & -0.7581 & -0.2079 & -0.6640 & 0.7930 \\
\hline TrainUnSkdPgeI & $2.4208 * *$ & $2.3826^{*}$ & $2.4362 * *$ & $3.6577 * *$ \\
\hline TrainComPgeI & 1.0613 & 0.6416 & 1.0269 & 0.3994 \\
\hline TrainMgtPgeO & -2.1374 & -1.4665 & -2.5550 & 1.7590 \\
\hline TrainPflPgeO & -2.7574 & -0.7661 & -2.7982 & -4.6779 \\
\hline TrainClcPgeO & 3.1795 & -2.4312 & 2.3145 & -11.2014 \\
\hline TrainCrftPgeO & -0.7731 & -1.2899 & -0.3902 & -3.6662 \\
\hline TrainUnSkdPgeO & -0.3989 & 1.6455 & -0.0245 & 2.5408 \\
\hline TrainComPgeO & $-3.4786 *$ & $-5.0970 *$ & -3.3083 & -1.4777 \\
\hline TradeAssociation & 0.0292 & 0.2174 & -0.1322 & 0.8991 \\
\hline Subcontract & $-0.8429^{+}$ & $-1.2421^{*}$ & $-0.7969^{+}$ & 0.9267 \\
\hline TffRawMtlPge & $-1.0588 * *$ & $-1.6437 * * *$ & $-1.0342 * *$ & -1.0855 \\
\hline RawMImptdPge & $0.0204 * *$ & $0.0199 * *$ & $0.0222 * * *$ & $0.0179^{+}$ \\
\hline UnsoldAvPge & 0.0106 & 0.01441 & 0.0089 & 0.0222 \\
\hline FirmSize & -0.0000 & 0.0002 & 0.0000 & 0.0002 \\
\hline Age & -0.0342 & -0.0243 & -0.0349 & -0.0501 \\
\hline $\mathrm{LAge}^{2}$ & $0.3279^{+}$ & 0.3400 & 0.3145 & -0.0058 \\
\hline LearningByDoing & $-0.0405^{+}$ & -0.0077 & $-0.0397^{+}$ & -0.0170 \\
\hline LAvSales/K & & $-0.7392 * *$ & $-0.5064 *$ & $-0.6702^{*}$ \\
\hline WagePremium & & $-0.0530^{+}$ & & \\
\hline RawMatl_Proximity & & & $-0.4004^{+}$ & \\
\hline RetrechmentPge & & & & $-2.6157^{+}$ \\
\hline Adjusted $\mathrm{R}^{2}$ & 0.4670 & 0.4780 & 0.4776 & 0.4162 \\
\hline $\mathrm{F}$ & 4.89 & 4.11 & 4.94 & 2.69 \\
\hline $\mathrm{P}$ & 0.0000 & 0.0000 & 0.0000 & 0.0008 \\
\hline $\mathrm{N}$ & 152 & 120 & 152 & 84 \\
\hline
\end{tabular}




\begin{tabular}{||r|l|l|l|l||}
\hline Ramsey reset test - F & 2.16 & 2.22 & 2.55 & 0.63 \\
$\mathrm{p}$ & 0.0971 & 0.0924 & 0.0595 & 0.6020 \\
\hline Cook-Weisbergtest-Chi2(1) & 0.03 & 0.26 & 0.23 & 0.14 \\
$\mathrm{p}$ & 0.8739 & 0.6104 & 0.6326 & 0.7066 \\
\hline \multirow{2}{*}{$* * *$ significant at $0.001, * *$ significant at $0.01, *=$ significant at $0.05,^{+}=$significant at 0.1} \\
\# Key of all variables used in above regressions is shown below \\
\hline
\end{tabular}

Table 3 cont. Key or definitions of Variables used in above regressions

\begin{tabular}{|c|c|}
\hline LExport/K * & Average exports $\div$ total replacement value of machinery \& equipment. \\
\hline LNewInvest & $\begin{array}{l}\text { Average new investment made in machinery } \& \text { equipment } \div \text { total replacement } \\
\text { value of machinery } \& \text { equipment. }\end{array}$ \\
\hline LCapital/Employee & Total replacement value of machinery $\&$ equipment $\div$ total workforce \\
\hline ForgnOwnShp** & Ownership dummy $($ Foreign $=1$, Domestic $=0)$ \\
\hline Sectdum $1-8$ & $\begin{array}{l}\text { Sector dummies (Sectdum } 1=\text { Chemical products, } 2=\text { Electrical/electronic } \\
\text { machinery, } 3=\text { Food processing \& beverages, } 4=\text { Iron \& Steel, 5= Metal } \\
\text { products, 6= Paper \& furniture, } 7=\text { Textiles, } 8=\text { Vehicles \& automotive } \\
\text { components) }\end{array}$ \\
\hline LInhseSpTrng & Amount spent on 'in-house' training $\div$ total value of machinery/equipment \\
\hline LOstSpTrng & Amount spent on "outside" training $\div$ total value of machinery/equipment \\
\hline TrainMgtPgeI & Number of Management staff on in-house training $\div$ total workforce \\
\hline TrainPflPgeI & Number of Professional/technical staff on in-house training $\div$ total workforce \\
\hline TrainClcPgeI & Number of Clerical/service workers on in-house training $\div$ total workforce \\
\hline TrainCrftPgeI & Number of Crafts, trades, operators on in-house training $\div$ total workforce \\
\hline TrainUnskldPgeI & Number of unskilled labour on in-house training $\div$ total workforce \\
\hline TrainComPgeI $* * *$ & Number of 'combined' categories on in-house training $\div$ total workforce \\
\hline TrainMgtPgeO & Number of Management staff on 'off-the-job' training $\div$ total workforce \\
\hline TrainPflPgeO & $\begin{array}{l}\text { Number of Professional/technical staff on 'off-the-job' training } \div \text { total } \\
\text { workforce }\end{array}$ \\
\hline TrainClcPgeO & Number of Clerical/service workers on 'off-the-job' training $\div$ total workforce \\
\hline TrainCrftPgeO & Number of Crafts, trades, operators on 'off-the-job' training $\div$ total workforce \\
\hline TrainUnskldPgeO & Number of Unskilled workers on 'off-the-job' training $\div$ total workforce \\
\hline TrainComPgeO*** & Number of 'combined' categories on 'off-the-job' training $\div$ total workforce \\
\hline TradeAssociation & Member of a Trade Association dummy $(1=$ member, $0=$ not a member $)$ \\
\hline Subcontract & Does firm subcontract production and/or marketing activities ( $\mathrm{Yes}=1, \mathrm{No}=0$ ) \\
\hline TffRawMtlPge & Has reduction in import duty tariff lowered material prices $(\mathrm{Yes}=1, \mathrm{No}=0)$ \\
\hline RawMImptdPge & Average percentage of total value of material inputs that was imported \\
\hline UnsoldAvPge & Average percentage of total output that remained unsold \\
\hline FirmSize & Total number of full-time employees in the firm \\
\hline Age & When did production start at this Plant? \\
\hline LearningByDoing & Average length of producing the three (3) most important products \\
\hline RawMatl_Proximity & $\begin{array}{l}\text { Rank plant's location to raw materials ( } 1=\text { Excellent, } 2=\text { Fair, } 3=\text { Poor, } 4=\text { Not } \\
\text { applicable) }\end{array}$ \\
\hline WagePremium & $\begin{array}{l}\text { Wage bill paid to non-production workers } \div \text { Production workers' wage bill paid } \\
\text { Average sales } \div \text { total replacement value of machinery \& equipment. }\end{array}$ \\
\hline LAvSales/K & Number of employees retrenched $\div$ total workforce \\
\hline RetrenchmentPge & \\
\hline
\end{tabular}


* = Dependent Variable is in bold. In Regression 4, the '\% of output exported' [LExportPge] is taken as the Dependent Variable.

** $=$ A firm is classified as 'Foreign-owned' if percentage of total assets that is foreign owned is $\geq 10 \%$.

$* * *=$ "common" training programs are those training programs which are not tailored to particular employee categories. Mixture of employees from different skill categories (i.e., management, professional/technical, crafts/trades, unskilled, etc.) attend such training programs.

Source: Computed from World Bank/GJMC Survey dataset

Increasing the number of unskilled workers attending in-house training programs (TrainUnSkdPgeI) has a positive impact on exports, which is probably related to the need to manufacture high quality products that are exportable. Our findings seem to mirror the results of a study of Brazilian exporting firms. Bastos et al. (2016) found that 'export participation' among Brazilian manufacturing firms had a positive effect only on the share of workers that received 'technical training', but was not associated with shares of workers who received training of other types. Surprisingly, increased exports seem to be associated with firms that had reduced the number of workers sent to off-the-job training programs that were catering for 'common' employees' categories (TrainComPgeO). The decline in the number of employees sent to 'off-the-job' training programs might have been caused by increasing retrenchments, decline in training budgets, and/or restructuring of training budgets. It is also possible that external training had become more specialised, targeting specific occupational categories. A study by Bhorat and Lundall (2004) found that most firms preferred in-house training to outside training sources. Further research needs to be done to disentangle the various factors driving the decline in workers' participation in off-the-job training programs.

One of the surprising results from the regressions shown in Table 3 is the non-significant association of a number of training variables with exports. On-the-job and off-the-job training of a larger share of Management staff, Professional/technical staff, and Crafts, trades \& plant machine operators does not seem to have any significant positive association with exports. Intuitively, one would expect some training of such categories of employees to have a direct positive impact on exports (Mital et al., 1999; Aw et al., 2007). As indicated earlier, the result probably suggests the need to have a reexamination of the structure, content, and quality of training programs offered to such occupational groups. There is a probable need to be critical of training programs being run by or offered to firms, especially training sourced from outside. Are such training programs really contributing to the competitive capabilities of firms? There is growing evidence that public policy initiatives to address the insufficiency of relevant workers' skills, such as the 'Sector 
Education Training Authorities (SETAs)', have been found to be an "ineffective vehicle for promoting workplace education and training" (Kleynhans \& Labuschagne, 2012, p75).

In general, exporting through subcontracting arrangements especially with foreign overseas buyers or Transnational Corporations (TNCs) - did not seem to play a significant role in aiding export-expansion among sample firms, probably later with the exception of the Motor vehicle sector. Several studies on East Asian firms have indicated the importance of subcontracting relationships with overseas buyers and TNCs, in driving technological progress and competitiveness of local firms (Aw et al., 2007; Diao et al., 2006). In a study on Malaysian electronic firms, it was found that subcontracting and sales to foreign firms played an important and significant catalytic role in the upgrading and deepening of technological capabilities of local firms (Noor et al., 2002). Linkages with foreign buyers and TNCs provided several benefits and resources to local firms in East Asian economies (i.e., input supply, international market access, technical assistance to meet product specifications of TNCs, training of local staff, assistance with acquisition of leading edge technologies, management skills, etc.). However, local firms' appropriation of knowledge spillovers from linkages with TNCs depends on several factors such as the stage of production activities local firms are involved in International Production Networks (IPNs), their respective competitive capabilities, the marketing and upgrading strategies of 'lead' TNCs firms, and the nature of power relationships among firms connected in such IPNs (Staritz \& Morris, 2013; Roberts, 2001; Barnes et al., 2003). A good discussion of the impact of different forms of IPNs on the competitiveness and upgrading prospects of local firms, different strategies used by 'Lead' firms to control such networks, and the implications of the differences between 'Buyer-driven' and 'Producer-driven' commodity chains is given in Yun (2003) and Raikes et al. (2000).

Increased imports of raw material inputs - accessed at international prices - seemed to have had a positive impact on initial exports. This is likely to be more valid in a subsector like 'Vehicles \& components', which had benefited from government incentives provided through the Motor Industry Development Programme (MIDP) introduced in 1995 (Kaplan, 2003; Barnes et al., 2003). This industry-specific supportive MIDP was later re-named 'Automotive Production and Development Program'. The import-export complementation (IEC) scheme enabled motor assemblers and component manufacturers to offset the cost-raising impact of the Rand's devaluation on imported intermediate inputs. The duty credits earned under the IEC scheme allowed motor assemblers/components manufacturers to effectively import intermediate inputs duty-free (Kaplan, 2003; Barnes et al., 2003). The complementary relationship between exports and imports is reinforced in 
situations where expanding exports increasingly use relatively cheaper and better imported capital and intermediate inputs. Over $70 \%$ of South Africa's imports had been classified as having a high capital- or intermediate capitalintensity (Edwards, 2001b). A good portion of these imports end-up as complement inputs to local production (Bhorat, 2000). However, the extent to which such process represents a 'shallow' industrialisation path is not clear in our sample. A study of Thailand enterprises found that the so-called "hightech" exporters were merely involved in low-skill processing and assembling of imported "high-tech" inputs (Lauridsen, 2002). The opening up of Eastern European economies to international competition initially precipitated a retreat into lower value-added manufacturing activities that had lower technological content (Radosevic, 1995).

The technological downgrading/simplification became the natural progression path taking into account the technical capabilities of (previously protected) local firms vis-à-vis international competitors in the 'new' liberalised environment. Examining manufacturing output growth, Fedderke (2002) finds that the 1990s was characterised by a strong link between capital stock and output growth, with technological innovation playing a declining role. Growth of output was underpinned by capital accumulation, rather than increased technological content linked to local innovations. Similar trend results have been documented by Kaplan (2014), with regard to declining share of technology intensive manufacturing and innovation in South Africa relative to peer BRICS countries. BRICS countries are Brazil, Russian Federation, India, China, and South Africa.

In contrast to the sign of the coefficient on imported inputs, there is some suggestion from the regression result that most firms did not view the reduction of duty on imported inputs (TffRawMtlPge) to have had a positive and significant impact on exports. Where such a claim is true, it may suggest that access to a greater variety of high quality imported inputs, rather than price competitiveness of such inputs, might have underpinned the observed complementary relationship between imports and exports. The complementary relationship, however, might well be sector specific (Bhorat, 2000). Interpretation of the above result must be taken with great caution. The positive impact of a reduction in import duties of imported inputs is likely to be neutralised if simultaneously undertaken with a significant devaluation of the local currency - especially in areas where there are no incentives to offset such effects. In such an environment, firms are unlikely to see the positive impact of a reduction in import duty, even when it does exist. In any case, the indicator (TffRawMtlPge) used here to capture the impact of increased trade openness is weak.

The relationship between exports and age of a firm has been found to be ambiguous (van Dijk, 2002). Some studies have found that younger firms 
tend to be more dynamic and more likely to export (Lee \& Brasch, 1978; Ursic \& Czinkota, 1984). Older firms may have the resources and operating experience to venture into export market (Lee \& Yang, 1990). Other studies have found that there is no relationship between exporting and age of the firm (Bhaduri \& Ray, 2004; Diamantopoulos \& Inglis, 1988). In our first regression, the age of the firm $\left(\mathrm{LAge}^{2}\right)$ seemed to have a significant positive non-linear relationship with exports, though it was only significant at $10 \%$ significance level. Older firms seem to have exported more of their output than younger firms. Similar results have been found in much of the literature on other countries. Older firms, which are likely to enjoy bigger experience-curve benefits, can afford to invest in technological upgrading, may have larger market share which lowers unit costs, and are likely to employ relatively high skilled workforce which is key to higher productivity needed to target competitive overseas markets (Bastos et al., 2016; Purfield et al., 2014; Rankin, 2013). However, the age of products manufactured for export markets (LearningByDoing) is negatively related to output that is exported. 'LearningByDoing' is the average age of three most important products or product lines sold by each firm. Lower average age represents 'newer' products or product lines. In other words, firms had used recently introduced products (or product lines) to target export markets. The results seem to confirm the importance of frequent product upgrading or product innovations when attempting to exploit competitive export markets. It is worthy to note that in Regression 1 (Reg 1), product upgrading variable (LearningByDoing) rather than machinery/equipment upgrading variable (LNewInvst97_8) plays a significant impact on the amount of output exported. The importance of incremental product innovation is critical when foreign markets have different demand characteristics to that of domestic market. In developing countries' conditions, learning, local adaptation, and incremental (product \& process) innovations taking place on the factory-floor is just as important as seeking new markets or efforts aimed at moving up market of existing target markets (Aw et al., 2007; Diao et al., 2006).

The variable 'UnsoldAvPge' was included in Regression 1, as a first attempt at capturing the 'distress-export' hypothesis. The objective is to answer the following question: Are exports positively related to firms that had large unsold output? The coefficient of the 'UnsoldAvPge' variable is not significant in Regression 1 (and also in other subsequent regressions). The non-significance of the 'UnsoldAvPge' coefficient does not necessarily disapprove of the validity of the 'distress-export hypothesis' applying to South Africa's manufactured exports (as will be discussed later). However, it indicates the probable non-existence of a significant positive correlation between the two variables when examining total aggregate exports among 
sample firms. It may be that the 'UnsoldAvPge' variable is a poor measure of 'distress-exports'.

Membership to trade associations (TradeAssociation) does not seem to have a significant impact on exports among sample firms. Such institutions did not (then) seem to have the capacity and experience to provide specialised export-related services that would assist firms restructure to a point where most firms were internationally competitive. However, a scenario of technically-weak trade associations during the early period of structural reforms is not unique to South Africa. Similar results were found in Mexico (Bair \& Gereffi, 2001) and Chile (Perez-Aleman, 2000). Like manufacturing firms, trade associations themselves need to 'reinvent' themselves into competent restructuring agents and providers of demand-driven services. Technical competencies of trade associations and other supporting institutions that are 'carry-overs' from previous closed economic environments should never be taken as a 'given'.

Regression 2 (Reg 2) has two more variables introduced in the regression: Average Sales (LAvSales/K), and Wage premium (WagePremium). The inclusion of the 'LAvSales/K' variable was a second attempt to capture the "vent-for-surplus" hypothesis: Was exporting associated with declining total sales? The second variable introduced (WagePremium) was meant to check whether firms that were exporting had higher or lower wage premiums. The results do provide some support for the "vent-for-surplus" hypothesis. Firms that exported more of their output (relative to their total output) seem to be those that had lower or declining total sales. Some sample firms seem to have moved into export market only after experiencing some market shocks to domestic demand. This is more true of medium-sized exporters who focused on neighbouring Southern African Development Community (SADC) markets (Rankin, 2013). The finding seems to be in line with earlier studies suggesting a positive correlation between domestic demand and sales/output growth (Roberts, 2000; Edwards, 2001a; 2001b). By running an extended cointegration regression across a number of South African manufacturing subsectors, Van Rensburg and Naude (1999) found that domestic output expansion had a much stronger positive impact on productivity growth than exports. For subsectors like Tobacco and Machinery products, they found that only the expansion of domestic demand had a significant positive impact on productivity growth in those sub-sectors. Their results corresponds with another study that found that, for most of the manufacturing subsectors in South Africa, economies of scale driven by domestic demand expansion seems to be the main determinant of productivity growth (Piazollo \& Wurth, 1995). Some medium-sized manufacturing firms had initially been 'pushed' into (SADC) export markets, which was partly due to a decline in domestic demand (Rankin, 2013; Matthee et al., 2016). 
The wage premium variable (WagePremium) had a moderate negatively significant association with exports in Regression 2. The coefficient is only significant at $10 \%$ significance level. The result some-what contradict a prior expectation that South Africa's manufacturing exports were becoming more capital-intensive and, hence, it is likely to be associated with higher wage premiums. However, the sign on the 'WagePremium' coefficient seems to support earlier result related to the capital-intensity coefficient in Regression 1 - that exports among sample firms were associated with less capital-intensive firms in our sample. As indicated earlier, the above finding might partly be picking up regional characteristics of the majority of firms found around Greater Johannesburg Metropolitan Council (GJMC) area, where the survey was conducted.

Regression 3 focused on the relationship between exports and proximity to raw materials. It has been argued that most of South Africa's exports are traditionally resource-based (Rankin, 2002; Nordas, 1996). Therefore, it is important to interpret the sign of the coefficient of RawMatl_Proximity variable properly. The sign is related to the way the coding was done: 1 = excellent, 2 = fair, 3 = poor, etc. A smaller value or negative value represents excellent location of the plant to raw materials. The sign of the coefficient on the RawMatl_Proximity variable suggest that nearness of production to raw materials seem to have a moderately significant and positive impact on export. The result re-enforces the dominance of resource-based manufactured exports in South African manufactured exportbasket discussed earlier. The coefficient is only significant at $10 \%$ significance level. Regression 4 tries to examine the relationship between exports and retrenchment. Even in the presence of other variables, export competitiveness seems to be associated with retrenchment of the workforce. In the liberalising environment, firms were increasing their efficiency by becoming leaner and smarter, retaining and/or increasing skilled labour while at the same time, dispensing-off the bulk of unskilled labour (Bhorat, 2000). However, competitiveness achieved through the laying-off of workers may be a competitive imperative in the short term, but only confer a one-off improvement. The introduction of the 'Retrenchment' variable significantly reduced the number of sample firms included in the regression equation. As such, very little analysis was made on this regression equation.

\section{Conclusion}

It must be emphasized that South African manufactured exports are overshadowed by a large mineral export sector (Anand et al., 2016; Purfield et al., 2014). By definition, the mineral sector tends to be capital-intensity and venerable to fluctuations in international commodity price. Hope for higher job creation, increased sustainable economic growth, and injection of high 
value-added technology-based products rest with an expanded vibrant manufacturing sector that is characterised by high dynamism (Purifield et al., 2014). As South Africa progresses into its second decade of economic reform and restructuring, questions are being asked about why this has not been achieved or why the results have been mixed at best (Edwards \& Jenkins, 2013; Rodrik, 2008; Edwards \& Alves, 2005).

Trade liberalisation of the economy can provide an additional means for mineral-based economies to develop their manufacturing export base, inject new dynamism into the economy, enhance economic growth, create additional jobs and increased income for associated workers (Rankin, 2013; Matthee et al., 2016; Purfield et al., 2014). Opening the domestic economy increases competitive pressures on both domestic and export-oriented firms. This forces local firms to improve their competitiveness, by improving productivity via technological upgrading and skill upgrading. Increased competition to import competing firms may even be beneficial to the whole economy, if it lowers input costs of intermediates produced locally. Consequently, accompanying technological upgrading may result in retrenchment of some (less productive) unskilled workers. This means that capital deepening is labour substituting. Skill upgrading requires increased education and training of the remaining existing workers. The added skills will, in turn, increase the wage earnings of unskilled production workers who received the training and have survived the initial retrenchment.

Manufactured exports provide additional benefits to firms and countries that succeed. These benefits include expanded global markets that help to achieve scale economies necessary to spread large fixed costs over a larger output base, opportunities for domestic firms to learn the demand characteristics of sophisticated consumers in developed economies, multiplier effects to other sectors in the economy, and as a means to diversify mineraldependent economies through increased value-addition to their natural endowment (Pan-African Investment \& Research Services, 2011; Faulkner et al., 2013). In order for the outlined scenario to happen, a number of preconditions need to be met. In this study, we focused only on one pre-condition, i.e., the interaction between skills and exports.

The study tried to capture the variety of skills and mechanisms of knowledge accumulation that may underpin one market-related performance indicator (Exports) and long term competitive capabilities. Despite increasing exports from some manufacturing subsectors, there are still debates/questions on whether South African firms have achieved long-term dynamic efficiency, became exporters of certain product lines on the back of various past government incentives and imported inputs, and/or if trade liberalization has merely re-enforced the country's comparative advantage in natural-resource endowed exports. Admittedly, various economic, social, and political 
processes simultaneously played a critical role in supporting export expansion of manufacturers, especially during the first decade of the reform period.

The regression results support the perspective that different knowledge accumulation channels (or learning mechanisms) may have differential impact on exports. With respect to manufactured exports, training a larger share of 'unskilled production workers' seem to enhance exporting capabilities. Their skills upgrading may have gone hand-in-hand with capital deepening that has been observed across most of the South African manufacturing sector, partly driven by the need to produce quality 'export-grade' output, especially when targeting European and North American markets (Matthee et al., 2016; Rodrik, 2008). Training of a larger proportion of employees from other occupational groups did not have an impact on exports. The results raise questions about the quality, content, and focus of employment-based training programs offered to other occupational categories. Exporting was associated with declining total sales. Some firms initially moved into export markets after experiencing demand shocks in domestic market. A large number of sample firms that export to SADC countries are partly driven by similar demand patterns in these countries. However, exporting to SADC countries may not provide a strong learning impetus for firms to engage in vigorous and frequent technological upgrading, which is central to achieving internationally competitive productivity levels. In terms of firm-level capability-building, the type of trading partner(s) that domestic firms trade with is equally important (Matthee et al., 2016; Rankin, 2013).

There is a complementary relationship between imports of raw materials/intermediate inputs and exporting. The complementary relationship confirms previous studies that have suggested the equal importance of imports and exports in re-enforcing/intensifying firm-level based learning and capability accumulation. The complementary relationship can build dynamic competitive advantage if the need to produce 'export-grade' output and subsequent step-by-step process/product upgrading, drives the importation of intermediate and capital inputs (Mayer, 2001; Aw et al., 2007). In addition, newly introduced product lines had a positive impact on exports, suggesting the importance of frequent product upgrading in exploiting competitive and demanding overseas export markets. Trade associations did not seem to have a significant positive impact on exports. Technical capabilities of trade associations to provide relevant know-how needed by firms to be competitive in overseas markets must not be taken as a 'given'.

\section{Implications}

There are several implications both at the firm- and national-level arising from the above results, which might be relevant to other resource-based economies. Such implications might include the following; 
i. Skill upgrading of 'unskilled production workers' through in-house employment-based training is important to ensure production of quality 'export-grade' output.

ii. There is an urgent need for future research to examine possible reasons why training expenditures spent on other occupational categories of employees (other than unskilled workers) did not have any significant association with exports. The first suspect could be the quality and relevance of educational and training programs offered to different occupational groups.

iii. The complementary relationship between imports and exports suggests that public policy should focus on further reduction of import tariff on imported intermediate inputs, as one means to accelerate export-led economic growth.

iv. The importance of frequent product upgrading when targeting demanding export markets suggests the need to have policy objectives that strengthen the National Innovation System, by encouraging the integration of innovation capabilities of all economic agents (i.e., manufacturing firms, TNCs, Education institutions, technical services providers, consultancy, foreign buyers, etc.).

v. The importance of creating a macroeconomic environment that supports the reforming of complementary innovation-supporting institutions (e.g., trade associations, universities, technical services providers, consultancies, national research institutions, etc.) is just as important as (market-led) restructuring taking place inside manufacturing firms.

vi. The need to 'manage' structural economic reforms/trade liberalization so that it is linked to firm-level capability building and strengthening of complementary supporting institutions is as important as implementing the structural reforms. However, 'managed' opening up of an economy requires effective government institutions that are relatively free from 'capture' by counter-reform vested interest groups, and implementation of 'sunset' clauses linked to productivity growth in firms receiving time-bound tariff-based protection.

vii. As the reform measures unfolds over time, the manufacturing sector and performance of manufactured exports have faced binding constraints that go beyond the capacity of individual firms to address them. These include lack of skilled labour (made worse by migrations of skilled labour outside South Africa), infrastructure bottlenecks, relatively low competition within the 'domestic product market' as evidenced by relatively high mark-up compared to peer countries, rising energy costs, need to contain growth in labour costs, etc. (Anand et al., 2016; Purfield et al., 2014; Kleynhans \& Labuschagne, 2012; 
Bhorat \& Rooney, 2017; Driver, 2019; IBRD, 2018; Department of Research \& Information, 2019). These challenges and their impact on competitiveness of locally based firms often need to be addressed through corroborative efforts between government policy makers, employers, workers, chambers of commerce, and other supporting institutions (i.e., universities, training providers, technical service providers, etc.). The need to develop internationally competitive manufacturing firms cannot be left to top managers or owners of manufacturing firms alone (ILO, 2011).

\section{Research Limitations}

Despite the above illuminating findings, the study had several limitations. Firstly, since the data used in the analysis was drawn within the first decade of economic reforms, our findings may apply only to the early decade of South Africa's structural reform. However, other studies done as late as 2010 onwards still found a declining trend in growth rate of South African exports. For example, a study by Purfield et al. (2014) found that between 2005 and 2011, the real growth rate of South African exports (in U.S dollars) declined to an annual average of $0.6 \%$. Other studies have also indicated a stagnation or declining growth rate in manufacturing competitiveness of exports over time (i.e., Edwards \& Jenkins, 2013; Matthee et al., 2016; Bhorat \& Rooney, 2017; Driver, 2019; IBRD, 2018; Francis et al., 2019; Mazorodze, 2019). Needless to say, longitudinal studies are required to take into account changes over time. This may require investment in detailed firm-level surveys that may be beyond the resources available to a single researcher. The relationship between technology, skills, and export is dynamic and may change over time. However, our findings are still relevant to other African and pacific countries that may be contemplating the implementation of introducing bold economic reform measures (i.e., Ethiopia, Zimbabwe, Angola, Papua New Guinea, etc.). Secondly, since the survey data used in this study is from Gauteng province, some of our findings might apply mainly to the manufacturing sector in Gauteng. Caution is required when extrapolating to other provinces that may be different. Lastly, a combination of incentives (i.e., competitive pressures, growth prospects, government support, TNCs strategies, etc.), state of factor markets (i.e., information, financial, different skills, unskilled labour, raw material inputs, etc.), and institutions (i.e., legal \& regulatory framework, educational institutions, product standards, etc.) interact to enable or disable a firm in its quest to strengthen its export capabilities. Some of these factors were not explicitly covered in this study. All the above limitations provide opportunities for further research. 


\section{References:}

1. Alleyne, T. \& Subramanian, A. (2001). What does South Africa's Pattern of Trade say about its Labour Market?, IMF Working Paper, No. WP/01/148, October, International Monetary Fund.

2. Almeida, R. \& Carneiro, P. (2006). The Return to Firm Investment in Human Capital, World Bank Policy Research Working Paper, No. 3851, The World Bank.

3. Altman, M. (2001). Employment Promotion in a Mineral Economy, Journal of International Development, Vol.13, pp. 691-709.

4. Anand, R., Perrelli, R. \& Zhang, B. (2016). South Africa's Exports Performance: Any Role for Structural Factors?, IMF Working Paper, No: WP/16/24, International Monetary Fund.

5. Aw, B. \& Batra, G. (1998). Technological Capability and Firm Efficiency in Taiwan (China), The World Bank Economic Review, Vol.12, No.1, pp. 59-79.

6. Aw, B.Y., Roberts, M.J. \& Winston, T. (2007). Export Market Participation, Investments in R\&D and Worker Training, and the Evolution of Firm Productivity, The World Economy, Vol. 30, No. 1, pp. 83-104.

7. Bair, J. \& Gereffi, G. (2001). Local Clusters in Global Chains: The Causes and Consequences of Export Dynamism in Torreon's Blue Jeans Industry, World Development, Vol.29, No.11, pp. 1885-1903.

8. Barnes, J., Kaplinsky, R. \& Morris, M. (2003). Industrial Policy in Developing Economies: Developing Dynamic Comparative Advantage in the South African Automobile Sector, IDS, University of Sussex, available at:

http://www.ids.ac.uk/ids/global/pdfs/RJ\&JB03.pdf (Accessed: 22-12015).

9. Basant, R. \& Chandra, P. (2002). Building Technological Capabilities in a Liberalising Developing Economy: Firm Strategy and Public Policy, Economics of Innovation and New Technology, Vol.11, No. 45, pp. 399-421.

10. Bastos, P. \& Silva, J. (2010). The quality of a firm's exports: Where you export to matters, Journal of International Economics, Vol. 82, No. 2, pp. 99-111.

11. Bastos, P., Silva, J. \& Proenca, R. (2016). Exports and Job Training, Policy Research Working Paper, No. WPS7676, The World Bank.

12. Beerepoot, N. (2004). Learning in small enterprises clusters: the role of skilled workers in the diffusion of knowledge in the Philippines, International Journal of Technology and Globalisation, Vol.1, No.1, pp. 78-91. 
13. Bell, M. (1984). Learning and the Accumulation of Industrial Technological Capacity in Developing Countries. In M. Fransman \& K. King (Eds.), Technological Capability in the Third World (pp. 187209). London: Macmillan Press.

14. Bell, M. \& Pavitt, K. (1993). Accumulating Technological Capabilities in Developing Countries, Proceedings of the World Bank Annual Conference on Development Economics 1992, The World Bank, Washington D.C.

15. Bell, T. \& Farrell, G. (1997). The Minerals-energy complex and South African Industrialisation, Development Southern Africa, Vol.14, No.4, pp. 591-613.

16. Berman, E., Bound, J. \& Machin, S. (1998). Implications of Skillbiased Technological change: International evidence, The Quarterly Journal of Economics, November, pp. 1245-1279.

17. Bhaduri, S. \& Ray, A.S. (2004). Exporting Through Technological Capability: Econometric Evidence from India's Pharmaceutical and Electrical/Electronics Firms, Oxford Development Studies, Vol.32, No. 1, pp. 87-100.

18. Bhavani, T.A. (2002). Impact of Technology on the Competitiveness of the Indian Small Manufacturing Sector: A Case Study of the Automotive Component Industry, UNU/WIDER Discussion Paper, No. 2002/76.

19. Bhorat, H. \& Rooney, C. (2017). State of Manufacturing in South Africa, Development Policy Research Unit Working Paper 201702, DPRU, University of Cape Town.

20. Bhorat, H. \& Lundall, P. (2004). Employment, Wages and Skills Development: Firm-Specific Effects - Evidence from a Firm Survey in South Africa, South Africa Journal of Economics, Vol. 72, No. 5, pp. 1023-1056.

21. Bhorat, H. (2000). The impact of trade and structural changes on sectoral employment in South Africa, Development Southern Africa, Vol.17, No.3, pp. 437-466.

22. Bigsten, A., Collier, P., Dercon, S., Fafchamps, M, Gauthier, B., Gunning, J.W., Habarurema, J., Oduro, A., Oostendorp, R., Pattillo, C., Soderbom, M., Teal, S., \& Zeufack, A. (2000). Exports and firmlevel efficiency in African manufacturing, Centre for the Study of African Economies, Oxford University, mimeo, July.

23. Bond, E.W., Jones, R.W. \& Wang, P. (2005). Economic Take-offs in a Dynamic Process of Globalization, Review of International Economics, Vol. 13, No.1, pp. 1-19.

24. Brambilla, I., Depetris-Chauvin, N. \& Porto, G.G. (2015). Wage and Employment Gains From Exports Evidence from Developing 
Countries, CEPII Working Paper, No: 2015-28, December. Available at:

http://www.cepii.fr/PDF_PUB/wp/2015/wp2015-28.pdf (accessed: 12-6-2016).

25. Caniëls, M.C.J. \& Romijn, H.A. (2003). Agglomeration Advantages and Capability Building in Industrial Clusters: The Missing Link, The Journal of Developing Studies, Vol.39, No.3, pp. 129-154.

26. Canuto, O., Dutz, M.A. \& Reis, J.G. (2010). Technological Learning and Innovation: Climbing a Tall Ladder, Poverty Reduction and Economic Management (Economic Premise) Network, No. 21, The World Bank.

27. Chandra, V., Moorty, L., Rajaratnam, B. \& Schaefer, K. (2001). Constraints to Growth and Employment in South Africa, World Bank Informal Discussion Paper, No.14, World Bank: Southern Africa Department.

28. Cohen, W.M. \& Levinthal, D.A. (1990). Absorptive Capacity: A New perspective on Learning and Innovation, Administrative Science Quarterly, Vol.35, pp. 128-152.

29. Department of Research \& Information (2019). Economic Overview: Recent developments in the global and South African economies, Industrial Development Corporation. Available at: https://www.idc.co.za/wp-content/uploads/2019/02/IDC-RIpublication-Economic-Overview-External-19-February-2019.pdf. (Accessed on: 1-12-2019).

30. Deloitte (2013). Enhancing Manufacturing competitiveness in South Africa, Deloitte Manufacturing Competitiveness Report, South Africa.

31. Diamantopoulos, A. \& Inglis, K. (1988). Identifying differences between high- and low-involvement exporters, International Marketing Review, Summer, pp. 52-59.

32. Diao, X., Rattso, J. \& Stokke, H.E. (2006). Learning by exporting and structural change: A Ramsey growth model of Thailand, Journal of Policy Modeling, Vol. 28, pp. 293-306.

33. Driver, C. (2019). Trade liberalization and South African manufacturing. WIDER Working Paper 2019/30. United Nations United World Institute for Development Economics Research. UNUWIDER. Helsinki, Finland.

34. Edwards, L. \& Jenkins, R. (2013). The impact of Chinese penetration on the South African Manufacturing sector, Southern Africa Labour and Development Research Unit, Working Paper Series, No. 102, Cape Town: SALDRU, University of Cape Town.

35. Edwards, L. \& Alves, P. (2005). South Africa's Export Performance: Determinants of Export Supply, Africa Region Working Paper Series, 
No. 95, The World Bank.

36. Edwards, L. (2001a). Globalisation and the occupational structure of employment in South Africa, South African Journal of Economics, Vol. 69, No. 1, pp. 40-71.

37. Edwards, L. (2001b). Trade and the structure of South African production;1984-97, Development Southern Africa, Vol.18, No.4, pp. 471-491.

38. Edwards, L. (2002). A Firm-level Analysis of Trade, Technology and Employment in South Africa, paper presented at TIPS Annual Forum, Glenburn Lodge, Muldersdrift.

39. Edwards, L. \& Lawrence, R. (2006). South African trade policy matters: Trade performance \& trade policy, CID South Africa Project Report, Harvard University, July.

40. Ernst, D., Ganiatsos, T. \& Mytelka, L. [eds.] (1998). Technological Capabilities and Export Success in Asia. London: Routledge.

41. Faulkner, D., Loewald, C. \& Makrelov, K. (2013). Achieving higher growth and employment: Policy options for South Africa, South African Reserve Bank Working Paper, No: WP/13/03.

42. Fedderke, J.W. (2002). The structure of growth in the South African economy: Factor accumulation and total factor productivity growth 1970-97, South African Journal of Economics, Vol.70, No.4, pp. 611645.

43. Felipe, J. \& McCombie, J.S.L. (2003). Some methodological problems with the neoclassical analysis of the East Asian Miracle, Cambridge Journal of Economics, Vol.27, No.5, pp. 695-721.

44. Figueiredo, P.N. (2002). Does technological learning pay off? Interfirm differences in technological capability-accumulation paths and operational performance improvement, Research Policy, Vol.31, pp. 73-94.

45. Fine, B. \& Rustomjee, Z. (1996). The Political Economy of South Africa: From minerals-energy complex to industrialisation, Johannesburg: Witwatersrand University Press.

46. Francis, D., Roberts, G. \& Valodia, I. (2019). South African manufacturing firms in transition, International Review of Applied Economics, Vol. 33, No. 1, pp. 71-92.

47. Galhardi, R.M.A.A. (1999). The impact of trade and technology on the skill profile in Brazil and the Republic of Korea, Employment and Training Paper, No. 40, International Labour Organization, Geneva.

48. Gereffi, G. (1999). International trade and industrial upgrading in the apparel commodity chain, Journal of International Economies, Vol.48, No.1, pp. 37-70.

49. Gries, T. (2002). Catching-up, Falling-behind and the role of FDI: A 
Model of endogenous growth and Development, South African Journal of Economics, Vol.70, No.4, pp. 588-610.

50. Hobday, M. (1995). East Asian latecomer firms: learning and the technology of electronics, World Development, Vol.23, No.7, pp. 1171-1193.

51. Hudson, R. (1999). The Learning Economy, the Learning Firm and the Learning Region: A sympathetic critique of the limits of learning, European Urban and Regional Studies, Vol. 6, No. 1, pp. 59-72.

52. IBRD (2018). South Africa Economic Update: Jobs and Inequality. Washington, DC: International Bank for Reconstruction and Development/The World Bank. Available at:

http://pubdocs.worldbank.org/en/798731523331698204/SouthAfrica-Economic-UpdateApril-2018.pdf. (Accessed: 1-12-2019).

53. ILO (2011). A Skilled Workforce or Strong, Sustainable and Balanced Growth: A G20 Training Strategy, International Labour Office Publication, November, International Labour Organization, Geneva.

54. Iyigun, M.F. \& Owen, A.L. (2006). Experiencing change and the evolution of adaptive skills: implications for economic growth, European Economic Review, Vol. 50, Issue 3, pp. 565-579.

55. Jonker, M., Romijn, H. \& Szirmai, A. (2006). Technological effort, technological capabilities and economic performance: A case study of the paper manufacturing sector in West Java, Technovation, Vol. 26, Issue 1, pp. 121-134.

56. Kaplan, D. (2003). Manufacturing Performance and Policy in South Africa - A Review, paper presented at TIPS/DPRU Forum, September.

57. Kaplan, D. (2014). Technology Intensive Manufacturing and innovation in South Africa: A Comparison with BRIC Countries and an Empirical Examination of Technology Based Firms, International Conference on Manufacturing led Growth for Employment and Equity, TIPS, 20-21 May 2014, Johannesburg, South Africa.

58. Karaoz, M. \& Albeni, M. (2005). Dynamic technological learning trends in Turkish manufacturing industries, Technological Forecasting and Social Change, Vol. 72, Issue 7, pp. 866-885.

59. Keller, W. (1996). Absorptive capacity: on the creation and acquisition of technology in development, Journal of Development Economics, Vol.39, No.3, pp. 86-100.

60. Kleynhans, E.P.J. \& Labuschagne, J.R. (2012). Human Capital Constraints in South Africa: A Firm-Level Analysis, Managing Global Transitions, Vol. 10, No. 1, pp. 69-86.

61. Kokko, A., Tansini, R. \& Zejan, M. (1996). Local Technological Capability and Productivity Spillovers from FDI in Uruguayan Manufacturing Sector, The Journal of Development Studies, Vol.32, 
No.4, pp. 602-611.

62. Lall, S. \& Latsch, W. (1998). Import Liberalisation and Industrial Performance: The Conceptual Underpinnings, Development and Change, Vol. 29, pp. 437-465.

63. Lall, S. (1992). Technological Capabilities and Industrialisation, World Development, Vol. 20, No. 2, pp. 165-186.

64. Lall, S. (1996). Paradigms of Development: The East Asian Debate, Oxford Development Studies, Vol.24, No.2, pp. 111-131.

65. Lauridsen, L.S. (2002). Coping with the Triple Challenge of Globalisation, Liberalisation and Crisis: The Role of Industrial Technology Policies and Technology Institutions in Thailand, The European Journal of Development Research, Vol.14, No.1, pp. 101125.

66. Lee, C.S. \& Yang, Y.S. (1990). Impact of export market expansion strategy on export performance, International Marketing Review, Vol.7, No.4, pp. 41-51.

67. Lee, W.Y. \& Brasch, J.J. (1978). The adoption of export as an innovative strategy, Journal of International Business Studies, Vol.9, pp. 85-93.

68. Machin, S. \& Van Reenen, J. (1998). Technology and changes in Skill Structure: Evidence from Seven OECD Countries, The Quarterly Journal of Economics, November, pp. 1215-1244.

69. Madanmohan, T.R., Kumar, U. \& Kumar, V. (2004). Import-led technological capability: a comparative analysis of Indian and Indonesian manufacturing firms, Technovation, Vol. 24, pp. 979-993.

70. Mainga, W. (2000). Firm-level Technological Capabilities in a liberalized environment: An examination of Zambian manufacturing firms after structural adjustment, unpublished PhD thesis, University of Bradford, UK.

71. Mainga, W. (2001). Firm-level capability building in less developed countries. In O. Morrissey \& M. Tribe (eds.) Economic Policy and Manufacturing Performance in Developing Countries, Cheltenham, UK \& Northampton MA, USA.

72. Matthee, M., Rankin, N., Naughtin, T. \& Bezuidenhout, C. (2016). The South African manufacturing exporter story, WIDER Working Paper, No. 2016/38, United Nations University-WIDER

73. Mayer, J. (2001). Globalization, Technology Transfer, and Skill Accumulation in Low-Income Countries, UNU/WIDER Discussion Paper, No. 2001/39, Helsinki, Finland.

74. Mital, A., Pennathur, A., Huston, R.L., Thompson, D., Pittman, M., Markle, G., Kaber, D.B., Crumpton, L., Bishu, R.R., Rajurkar, K.P., Rajan, V., Fernandez, J.E., McMulkin, M., Deivanayagam, S., Ray, 
P.S., \& Sule, D. (1999). The need for worker training in advanced manufacturing technology (AMT) environments: A White Paper, International Journal of Industrial Ergonomics, Vol. 24, pp. 173-184.

75. Mytelka, L.K. \& Tesfachew, T. (1998). The Role of Policy in Promoting Enterprise Learning During Early Industrialisation: Lessons for African Countries, UNCTAD/GDS/MDPB/Study No. 7.

76. Narayanan, K. (1998). Technology acquisition, de-regulation and competitiveness: a study of Indian automobile industry, Research Policy, Vol.27, pp. 215-228.

77. Navaretti, G.B., Galeotti, M. \& Mattozzi, A. (2004). Moving skills from hand to heads: does imported technology affect export performance in textiles? Research Policy, Vol.33, pp. 879-895.

78. Mazorodze, B. (2019). Trade and efficiency of manufacturing industries in South Africa, The Journal of International Trade \& Economic Development, DOI: 10.1080/09638199.2019.1640273

79. Naude, C. (2006). Measures of Manufacturing Industry Concentration: Implications for South Africa, Accelerated and Shared Growth in South Africa: Determinants, Constraints and Opportunities Conference, 18-20 October, Mulderdrift, South Africa.

80. Nelson, R.R. (1981). Research and Productivity Growth and Productivity difference: Dead Ends and New Departures, Journal of Economic Literatures, Vol.19, pp. 1029-1064.

81. Noor, H.M., Clarke, R. \& Drffield, N. (2002). Multinational Enterprises and Technological Effort by Local Firms: A Case Study of the Malaysian Electronics and Electrical Industry, The Journal of Development Studies, Vol.38, No.6, pp. 129-141.

82. Nordås, H.K. (1996). South African Manufacturing Industries Catching Up or Falling Behind?, The Journal of Development Studies, Vol.32, No.5, pp. 715-733.

83. Okada, A. (2004). Skills Development and Interfirm Learning Linkages under Globalization: Lessons from the Indian Automobile Industry, World Development, Vol.32, No.7, pp. 1265-1288.

84. Pan-African Investment \& Research Services (2011). Assessing the Manufacturing Sector and its Multiplier Effects on the South African Economy, Manufacturing Report, Manufacturing Circle of SA.

85. Pavcnik, N. (2003). What explains skill upgrading in less developed countries?, Journal of Development Economics, Vol.71, pp. 311-328.

86. Perez-Aleman, P. (2000). Learning, Adjustment and Economic Development: Transforming Firms, The State and Associations in Chile, World Development, Vol. 28, No.1, pp. 41-55.

87. Petersson, L. (2002). Integration and intra-industry trade adjustment in South Africa, Development Southern Africa, Vol.19, No.2, pp. 239- 
259.

88. Piazolo, M. \& Wurth, M. (1995). Productivity in the South African Manufacturing Industry: A Co-integration Approach, South African Journal of Economics, Vol.63, No.2, pp. 173-198.

89. Pretorius, A. (2002). The impact of Globalisation on the labour market in South Africa: Evidence from the manufacturing sector, paper presented at FES/DPRU Second Annual Conference on Labour Markets and Poverty in South Africa, Mulderdrift, Johannesburg, 9$11^{\text {th }}$ September.

90. Purfield, C. M., Farole, T. \& Im, F. (2014). South Africa Economic Update 5: Focus on Export Competitiveness, Report, Issue No. 5, World Bank Group: Africa Regional Poverty Reduction and Economic Management, Washington, DC.

91. Radosevic, S. (1995). Science and technology capabilities in economies in transition; effects and prospects, Economics of Transition, Vol.3, No.4, pp. 459-478.

92. Raikes, P., Jensen, M.F. \& Ponte, S. (2000). Global commodity chain analysis and the French filière approach: comparison and critique, Economy and Society, Vol.29, No.3, pp. 390-417.

93. Rankin, N. (2002). The Export Behaviour of South African Manufacturing Firms, TIPS Working Paper, No. 5.

94. Rankin, N. (2013). Exporting and Export Dynamics among South African Firms, South African Institute of International Affairs, Economic Diplomacy Programme, Occasional Paper No. 149.

95. Rivera-Batiz, L.A. \& Romer, P.M. (1991). Economic integration and endogenous growth, The Quarterly Journal of Economics, (May), pp. 531-555.

96. Roberts, S. (2000). Understanding the Effects of Trade Policy Reform: The case of South Africa, South African Journal of Economics, Vol.68, No.4, pp. 607-638.

97. Roberts, S. (2001). Globalisation, industrial development and the plastics industry in South Africa, Journal of International Development, Vol.13, No.6, pp. 797-810.

98. Rodrik, D. (2008). Understanding South Africa's economic puzzles, Economics of Transition, Vo. 16, No. 4, pp. 769-797.

99. Söderbom, M. \& Teal, F. (2000). Skills, Investment and Exports from Manufacturing Firms in Africa, The Journal of Development Studies, Vol.37, No.2, pp. 13-43.

100. Solleiro, J. \& Castanon, R. (2004). Competitiveness and innovation systems: the challenges for Mexico's insertion in the global context, Technovation, Vol. 25, Issue 9, pp. 1059-1070. 
101. Staritz, C. \& Morris, M. (2013). Local embeddedness, upgrading and skill development: global value chains and foreign direct investment in Lesotho's apparel industry, Capturing the Gains 2013, Working Paper 20. ISBN: 978-1-909336-99-5.

102. Suleman, A. \& Naudé, W. (2003). The Competitiveness of South African Manufacturing: A Spatial View, Journal for Studies in Economics and Econometrics, Vol.27, No.2, pp. 29-52.

103. Sun, H., Hone, P. \& Doucouliagos, H. (1999). Economic openness and technical efficiency: A case study of Chinese manufacturing industries, Economics of Transition, Vol.7, No.3, pp. 615-636.

104. Tam, T. \& Gereffi, G. (1999). Industrial Upgrading and Organizational Chains. Available at:

http://www.ids.ac.uk/ids/global/conf/pdfs/iuoc.pdf (Accessed: 26-5-2014).

105. Tsikata, Y. (1999). Liberalisation and trade performance in South Africa, World Bank Discussion Paper, No.13, The Southern Africa Department, Washington D.C., The World Bank.

106. Uchida, Y. \& Cook, P. (2005). The Transformation of Competitive Advantage in East Asia: An Analysis of Technological and Trade Specialisation, World Development, Vol. 33, No. 5, pp. 701728.

107. UNIDO (2003). Competing through Innovation and Learning, Industrial Development Report 2002/2003, Vienna, Austria.

108. Ursic, M.L. \& Czinkota, M.R. (1984). Experienced curve explanation to export expansion, Journal of Business Research, Vol.12, No.2, pp. 159-168.

109. Van Dijk, M. (2002). The Determinants of Export Performance in Developing Countries: The Case of Indonesian Manufacturing, ECIS Working Paper, No: 02.01, Eidhoven Centre for Innovation Studies, Technische Universiteit Eindhoven, The Netherlands.

110. Van Rensburg, J. L. \& Naudé, W.A. (1999). Productivity and Export Growth in the SA Manufacturing Sector, South African Journal of Economic and Management Sciences, Vol.2, No.2, pp. 269-291.

111. Wignaraja, G. (2001). Firm Size, Technological Capabilities and Market-oriented Policies in Mauritius, UNU/INTECH Discussion Paper Series, No. 2001-1, Maastricht, Netherlands.

112. Wignaraja, G. (2007). Foreign ownership, technological capabilities, and clothing exports in Sri Lanka, $A D B$ Institute Discussion Papers, No. 82.

113. Young, A. (1991). Learning by doing and the dynamic effects of international trade, The Quarterly Journal of Economics, May, pp. 
369-405.

114. Yun, C. (2003). International Production Networks and the Role of the State: Lessons from East Asian Development Experience, The European Journal of Development Research, Vol.15, No.1, pp. 170-193.

115. Yunus, N.M., Said, R. \& Azman-Saini, W.N.W. (2015). Spillover Effects of FDI and Trade on Demand for Skilled Labour in Malaysian Manufacturing Industries, Asian Academy of Management Journal, Vol. 20, No. 2, pp. 1-27. 